\title{
SYMPOSIUM ON COVID-19, GLOBAL MOBILITY AND INTERNATIONAL LAW
}

\section{FREE MOVEMENT OF PERSONS IN WEST AFRICA UNDER THE STRAIN OF COVID-19}

\author{
Abdoulaye Hamadou*
}

Immediately after the first signs of COVID-19 in West Africa in March-April 2020, twelve countries officially closed their borders. ${ }^{1}$ Other countries, such as Benin, Ivory Coast and Senegal, adopted a more pragmatic approach by merely limiting to essential crossings any arrivals or departures over land, and by adopting humanitarian corridors. ${ }^{2}$ Many of these measures are based on Article 4 of the 1979 Dakar Protocol of the Economic Community of West African States (ECOWAS) and Article 91 of the amended Treaty of the West African Economic and Monetary Union (known under its French acronym UEMOA), which authorize states to limit the freedom of movement and residence for reasons of public order, public security, or public health. The measures, however, have heavily impacted the legal regime of free movement of persons throughout the ECOWAS area. In the following analysis, I will show that the measures have (1) contributed to the disintegration of the legal regime of free movement of persons in ECOWAS and (2) instrumentalized COVID-19 for political ends in ways that are counterproductive for the region.

Free movement of persons is understood here as the right of persons to move to, settle in, and leave and return from another national territory at will. It constitutes a kind of security which the state provides to the individual and has the character of an unalienable right. ${ }^{3}$ More specifically, it has three components: the right to enter, the right to reside, and the right of establishment on the territory of ECOWAS member states. In West Africa, this right has historical, economic, and social justifications. It is laid down in texts of both the $\mathrm{UEMOA}^{4}$ and ECOWAS. ${ }^{5}$ From the point of view of these two regional legal orders as well as from a functional point of view, free movement appears as one of the fundamental and primary levers of West African integration. This freedom is so natural and eminently beneficial to the region that it is hard to imagine that it may be limited. But it is precisely the seemingly irreversible character of the mobility of persons in West Africa that has been profoundly impacted by the legal measures adopted to contain the spread of COVID-19.

* Faculty of Law, Economics and Management at the University of Taboua, Niger. Translated from French by Thomas Spijkerboer.

${ }^{1}$ The countries are Burkina Faso, Ivory Coast, Ghana, Guinea, Guinea-Bissau, Liberia, Mali, the Gambia, Niger, Nigeria, Sierra Leone, and Togo.

${ }^{2}$ UNHCR, Protection Note: Impact of COVID-19 on the Protection of Displaced and Stateless Populations - West and Central Africa (June 30, 2020).

${ }^{3}$ Simon-Pierre Zogo Nkada, La Libre Circulation des Personnes: Réflexions sur l'Expérience de la C.E.M.A.C. et de la C.E.D.E.A.O., REvUE Internationale de Droit Economique 2 (2011).

4 Treaty of the West African Economic and Monetary Union art. 91 (1994).

5 Economic Community of West African States (ECOWAS) Treaty art. 59, July 24, 1993, 2373 UNTS 233; A/P 1/5/79 Protocol Relating to Free Movement of Persons, Residence and Establishment art. 2, 1 O.J. ECOWAS 3 (June 15, 1979) [A/P 1/5/79 Protocol].

(C) Abdoulaye Hamadou, 2020. This is an Open Access article, distributed under the terms of the Creative Commons Attribution 337 licence (http://creativecommons.org/licenses/by/4.0/), which permits unrestricted re-use, distribution, and reproduction in any medium, provided the original work is properly cited. 


\section{A Disintegrating Legal Regime}

In the ECOWAS context, restrictions on the right to enter have led to a progressive disintegration of the legal regime of free movement of persons. A number of factors have contributed to this development.

According to the Dakar Protocol, the right of entry implies the guarantee that ECOWAS citizens can enter the national territory of all ECOWAS member states without a visa. The only condition is possession of valid travel documents. ${ }^{6}$ This is a first and indispensable step for making the free movement of persons effective because it conditions the expression and the effectivity of the other rights (namely of residence and establishment). ${ }^{7}$ For example, Nigerian nationals can only exercise their rights of residence and establishment in Ivory Coast or in Senegal if they have been authorized to enter the territory of those states. However, under pressure of the coronavirus, 66 percent of the 352 points of entry within the ECOWAS space were closed altogether, and 26 percent were only open to transport of goods and/or returning nationals. ${ }^{8}$ This constitutes a substantial obstacle to the right of entry.

The Dakar Protocol provides that "Member States shall reserve the right to refuse admission into their territory Community any citizen who comes within the category of inadmissible immigrants under its laws." The Protocol thereby gives the necessary legal basis for restrictions on movement by allowing states to refuse admission to "inadmissible immigrants." Moreover, ECOWAS texts do not define that term, so member states can interpret it - and have interpreted it - in accordance with political interests and short-term policies of economic protectionism. Indeed, in practice, recourse to this exception to free movement is entirely at the discretion of member states, who invoke it in a general manner for reasons of public order, public security, public health, or more generally in exceptional circumstances. The legality of any restrictions generally depends on whether they are reasonable and proportional to the aim pursued, but in light of the exception, and given that COVID-19 is a mobile and highly contagious illness, the virus has created opportune grounds for further limitations on movement.

To make matters worse, West African states have invoked the exception for "inadmissible immigrants" so often that a number of states now apply it practically as a matter of routine. For example, Nigeria decided unilaterally to close its borders with Benin, Ghana, and Niger for a protracted period in 2019, in violation of Article 2 of the Dakar Protocol. This protectionist measure limited the circulation of goods between Nigeria and its neighbors for the stated purpose of combatting smuggling, but it also seriously impacted the free movement of persons. ${ }^{10}$ Under the double pretext of insecurity and transnational crime, Mali and Niger have adopted a similar approach over the past few years in their restrictive and repressive management of the movement of community citizens headed for Libya and Algeria. ${ }^{11}$ COVID-19 measures have merely amplified the obstacles to the community principle of free movement, handicapping the integration dynamic which relies on the practices and realities of peoples in West Africa.

Two regional conditions further exacerbate these obstacles. One is the absence of supervision of member state implementation of ECOWAS laws by ECOWAS institutions. Despite the existential importance of free movement for regional integration, its application at the state level is not subject to any formal oversight on behalf of community citizens (think of the ECOWAS Parliament) or by community institutions (such as the ECOWAS

${ }^{6}$ A/P 1/5/79 Protocol, supra note 5, art. 3.

${ }^{7}$ Luc Marius Ibriga et al., Droit Communautaire Ouest Africain 30, 132 et seq. (2008).

${ }^{8}$ Int'l Org. Migration, West and Central Africa - Mobility Restrictions Linked to COVID-19 Within ECOWAS (July 22, 2020).

9 A/P 1/5/79 Protocol, supra note 5, art. 4.

${ }^{10}$ Le Nigéria a Décidé de Fermer ses Frontières Terrestres Pour Lutter Contre la Contrebande, BBC News (Nov. 4, 2019).

11 Abdoulaye Hamadou, La Gestion des Flux Migratoires au Niger Entre Engagements et Contraintes, La Revue DEs DroITs DE L'HOMme 13, 14 (June 27, 2018). 
Commission, Council of Ministers, or Court). Most notably, ECOWAS law allows for cases to be brought before the ECOWAS Court only by member states and specific ECOWAS institutions, not citizens. In addition, domestic courts cannot refer questions to the Court in a preliminary procedure, ${ }^{12}$ and the treaties and regulations implementing free movement do not oblige states to notify ECOWAS institutions (specifically, the ECOWAS Commission) of the nature and duration of any restrictions.

This supervision deficit empowers individual member states and undermines the legal framework of free movement of persons envisioned by ECOWAS law. As pointed out above, there is considerable variation in the limitation of movement under the COVID-19 measures between, for example, Benin on the one hand and Niger, Burkina Faso, or Mali on the other. This illustrates that member states remain sovereign entities with an exclusive competence over their territory when it comes to regulating the movement of persons and goods. ${ }^{13}$ The COVID19 crisis brings to light the tension between this exercise of state sovereignty that undermines regional integration, and the envisioned "partial and gradual pooling of national sovereignties to the Community within the context of a collective political will," as the Preamble of the ECOWAS Treaty puts it.

The second regional condition, related to the civic and legal climate in West African nations, lies in the absence of civil society engagement and limited public awareness of litigation as a strategy for rights enforcement. In the context of COVID-19, one might imagine that domestic courts could have prevented the generalized and systematic infringements on public freedoms that we have witnessed. Indeed, given the inability of citizens to bring claims before the ECOWAS Court, domestic courts might seem uniquely capable, at least in theory, of protecting the inalienable character of the freedom of movement. But the possibilities for domestic courts to scrutinize the reasonableness and proportionality of COVID-19 based restrictions are limited by a number of political, institutional, and legal factors. Some have argued that a weak separation of powers in the context of presidentialism and the related timidity of constitutional judges play a role. The absence of a human rights mandate for constitutional courts, the non-application of formally adopted monist doctrine in most countries, and limited standing for NGOs and members of the public further contribute to the lack of a culture of litigation. ${ }^{14}$ These conditions have further inhibited the accountability of ECOWAS member states in relation to measures infringing rights and freedoms.

The resulting restrictions on free movement have been particularly harmful to displaced persons, asylum seekers, and refugees, whose needs and vulnerabilities are generally disregarded. Only Ivory Coast has mentioned the creation of humanitarian corridors as an exception to border closure, with the aim of providing support to individuals or communities in need of urgent assistance. ${ }^{15}$ In the case of refugees and asylum seekers, the restrictions are problematic both in relation to the principle of non-refoulement and the right of every person to return to one's own country. In the so-called "three borders region," where the borders of Burkina Faso, Mali, and Niger meet, the risk of refoulement to thousands of people is quite real as a consequence of the state of emergency. As a result, these states may well violate their well-defined obligations of non-refoulement on the basis of Article 33 of the Geneva Convention on Refugees.

12 Protocol A/P.I/7/91 on the Community Court of Justice arts. 9 \& 10 (July 6, 1991).

13 Zogo, supra note 3, at 127.

${ }^{14}$ Serges Djoyou Kamga, An Assessment of the Possibilities for Impact Litigation in Francophone African Countries, 14 AFr. Hum. RTs. L.J. 449 (2014).

${ }^{15}$ UNHCR, supra note 2 , at 4. 


\section{The Instrumentalization of COV ID-19}

West African states have individually adopted COVID-19 related measures which they find appropriate to the urgency of the situation in light of their political and protectionist interests. These measures include the sanitary state of emergency (in Niger, Ivory Coast, Senegal, and Togo), the state of sanitary alert (in Burkina Faso), and lockdown with border closure (in all states except Benin). The justification given by governments for these measures is that they will curb the spread of the virus. But when one looks at their actual effects, the measures pose two problems: they have not brought about their intended benefit, and they have impacted free movement of persons in unexpected ways. My purpose here is to show that these excessively restrictive measures are scarcely compatible with West African realities and constitute an instrumentalization of the pandemic so as to limit freedom of movement.

In West Africa, neither border closures, nor the declaration of a state of sanitary emergency, nor curfews have helped to prevent a rise in COVID-19 cases and deaths in adopting states. By way of illustration, Benin, which has opted for flexible measures such as face masks and social distancing, has registered fewer deaths than Niger, Mali, or Burkina Faso, which had recourse to border closures and limitation of individual freedoms. This disconnect between the measures adopted and the aim pursued suggests that, in the largest part of West Africa, the responses to COVID-19 have not been well considered, balanced, contextualized, or coordinated.

While the adopted measures remain ineffective in most cases, they have produced at least two effects which are useful from a purely statist perspective. First, while such measures may be entirely legitimate, they have generally increased governmental prerogatives to restrict the freedom of movement even within countries. ${ }^{16}$ For example, the declaration of curfews in numerous countries has facilitated police violence and repression of individual freedoms. Such violence is contrary to national, ${ }^{17}$ regional, ${ }^{18}$ and international ${ }^{19}$ legal instruments to which all states are party.

Furthermore, states have instrumentalized COVID-19 to justify restrictions on the freedom of movement of community citizens and other African nationals. While the justification of the restrictions refers to COVID-19, they are part of a wider development that undermines the legal free movement regime in West Africa. This development is fed by both ill-conceived notions of economic protectionism, and by European policies which nudge or even pressure African states to undermine free movement among ECOWAS member states, and hence to stem migration both within West Africa as well as towards Europe.

While the above analysis points to the disintegration of the legal framework of freedom of movement through COVID-related policy, this disintegration is at odds with the social reality of mobility in the region and goes directly against regional socio-economic interests. From a social point of view, the mobility of populations in West Africa is so natural that it cannot be reconciled with border closure or strict lockdown measures. Also, African states do not control all of their borders enough to be able to enforce border closures effectively. For example, the Wodaabe (nomadic farmers and merchants) engage in seasonal migration which brings them from southern Niger to northern Nigeria; ${ }^{20}$ no border closure or lockdown will discourage them. Another major issue is that populations residing on both sides of the border often have social ties which are legally recognized, such as marriage. This can be

\footnotetext{
${ }^{16}$ Seni Mahamadou Ouedraogo \& Djibrihina Ouedraogo, Les élections Présidentielles et Législatives à l’Epreuve du COVID-19: Une Mise en Lumière en Afrique de l'Ouest Francophone, AFRILEX 2.

17 E.g., Nigerian Constitution of 1999 art. 14; Constitution of Benin art. 18.

18 African Charter on Human and Peoples' Rights arts. 4 \& 6, June 27, 1981, 1520 UNTS 217.

19 Convention Against Torture and Other Cruel, Inhuman or Degrading Treatment or Punishment art. 2, Dec. 10, 1984,1465 UNTS 85.

${ }^{20}$ Papa Demba Fall, Migration et Développement au Sabel. Au-delà des Leçons Apprises, Comment Mieux Tirer Parti des Mobilités?, (Int'l Centre for Migration Policy Dev. 7, 2016).
} 
seen at Niger's borders with Benin, Burkina Faso, and Nigeria, where numerous families continue to maintain historical ties of kinship.

Finally, the limitations are problematic from an economic point of view. Human mobility in West Africa contributes to the circulation of knowledge, commerce, investment, and culture. ${ }^{21}$ More concretely, and because of the low level of technological development in the region, the free movement of persons intimately conditions the circulation of goods. If one also takes into consideration the financial benefits for these populations (e.g., remittances sent back to family members), it is clear that West African states have little legitimate interest in disrupting human mobility. Unfortunately, the practice of states is not in conformity with this perception.

\section{Conclusion}

As has been shown, free movement of persons in West Africa poses a real governance problem. It is at the heart of an enduring confrontation between two perspectives: on one side, that of the population, a substantial part of which is nomadic and sees movement as a natural freedom; on the other side, that of states torn between diverging interests and at pains to come to grips with the social, economic, and cultural dimensions of free movement. ECOWAS states have relied on COVID-19 justifications to shut down cross-border movement, undermining the legal framework of free movement in the process. These recent developments occur in a broader context where, even pre-pandemic, states relied on various exceptions to capriciously curtail freedom of movement.

The measures are also questionable from a practical perspective. There has been no evidence that they have contributed to stopping the spread of the virus, and in fact, the economic and social interests of the region are better served by greater freedom of movement. The real motivations for the closures seem to have been both blunt economic protectionism and pressure from Europe to replicate the measures it has taken, including shutting down freedom of movement. In other words, what we see is the instrumentalization of the pandemic to reinforce regimes of immobility in the region, both at the behest of Europe and for short-term economic protectionism. West Africa should reconsider this approach and face its realities in a responsible manner. The mobility of persons is one of the main characteristics of the region and must be respected and promoted as a driver of peace, solidarity, and development. 